УДК 618.14-006.327-06:616.4-06:616.89-008.19

DOI 10.11603/24116-4944.2018.1.8751

\author{
${ }^{\circ}$ Н. О. Існюк, А. В. Бойчук, Б. М. Бегош, Б. О. Ониськів \\ ДВНЗ «Тернопільсъкий державний медичний університет \\ ілені І. Я. Горбачевсъкого МОЗ України»
}

\title{
ХАРАКТЕРИСТИКА ПСИХОЕМОЦІЙНОГО СТАТУСУ ТА ПОКАЗНИКІВ ЯКОСТІ ЖИТТЯ В ЖІНОК ІЗ ФІБРОМІОМОЮ МАТКИ ТА ПОЄДНАНОЮ ЕНДОКРИННОЮ ПАТОЛОГІЕЮ
}

\begin{abstract}
Мета дослідження - оцінити психоемоційний статус і показники якості життя в жінок із фріброміомою матки та поєднаною диссрункцією щитоподібної залози.

Матеріали та методи. Шляхом анкетування за допомогою психологічних методик проведено обстеження 35 жінок (основна група) та 20 практично здорових жінок репродуктивного віку.

Результати дослідження та їх обговорення. У жінок основної групи показники психоемоційних розладів були більш вираженими, ніж у контрольній групі. Відмічено переважання депресивних симптомів різного ступеня вираженості та емоційної лабільності. Згідно з наведеними результатами оцінювання показників якості життя, слід відзначити, що 55,5 \% осіб контрольної групи характеризують якість свого життя як високу, тоді як в основній групі подібну характеристику навели лише 5 \% пацієнток.

Висновки. Наявність поєднаних дисгормональних процесів різної локалізації негативно впливає як на психоемоційний стан, так і на якість життя жінок у всіх її сфрерах. Отже, вибір методу лікування даної категорії пацієнтів вимагає також індивідуальної психотерапевтичної реабілітації у зв'язку з їх вираженою емоційною лабільністю та низькою стресостійкістю.

Ключові слова: фріброміома матки; психоемоційний статус; якість життя; ендокринна диссункція.

ХАРАКТЕРИСТИКА ПСИХОЭМОЦИОНАЛЬНОГО СТАТУСА И ПОКАЗАТЕЛЕЙ КАЧЕСТВА ЖИЗНИ У ЖЕНЩИН С ФИБРОМИОМОЙ МАТКИ И СОЧЕТАННОЙ ЭНДОКРИННОЙ ПАТОЛОГИЕЙ

Цель исследования - оценить психоэмоциональный статус и показатели качества жизни у женщин с фибромиомой матки и сочетанной диссункцией щитовидной железы.

Материалы и методы. Путем анкетирования с помощью психологических методик проведено обследования 35 женщин (основная группа) и 20 практически здоровых женщин репродуктивного возраста.

Результаты исследования и их обсуждение. У женщин основной группы показатели психоэмоциональных расстройств были более выраженными, чем в контрольной группе. Отмечено преобладание депрессивных симптомов различной степени выраженности и эмоциональной лабильности. Согласно приведенных результатов оценки показателей качества жизни, следует отметить, что 55,5 \% лиц контрольной группы характеризуют качество своей жизни как высокое, тогда как в основной группе подобную характеристику привели лишь 5 \% пациенток.

Выводы. Наличие объединенных дисгормональных процессов различной локализации негативно влияет как на психоэмоциональное состояние, так и на качество жизни во всех ее сферах. Значит, выбор метода лечения данной категории пациентов требует также индивидуальной психотерапевтической реабилитации в связи с их выраженной эмоциональной лабильностью и низкой стрессоустойчивостью.
\end{abstract}

Ключевые слова: фибромиома матки; психоэмоциональный статус; качество жизни; эндокринная диссрункция.

THE CHARACTERISTICS OF PSYCHOEMOTIONAL STATUS AND INDICATORS OF LIFE QUALITY OF WOMEN WITH A DISEASE OF A FIBROMYOMA AND COMBINED ENDOCRINE PATHOLOGY

The aim of the study - to evaluate the psychoemotional status and life quality of women with a disease of a fibromyoma in combination with dysfunction of the thyroid gland.

Materials and Methods. The psychological questionnaires were made among the main group of 35 women and among 20 practically healthy women of reproductive age with the aim to examine them.

Results and Discussion. The women of the main group had more pronounced indicators of psycho emotional disorders than they were in the group of the healthy women. The predominance of varying degrees of depressive symptoms and emotional lability has been noted. According to the results it should be noted that $55.5 \%$ of the control group showed the high level of their life quality, while only $5 \%$ of patients in the main group reported this result.

Conclusions. The presence of combined dishormonal processes of different localization negatively affects both the psychoemotional state and the quality of life of women in all its spheres. Therefore, the choice of the treatment method for this category of patients also requires individual psychotherapeutic rehabilitation due to their expressed emotional lability and low stress resistance.

Key words: uterine fibroids; psycho-emotional status; quality of life; endocrine dysfunction.

ВСТУП. Одним із найпоширеніших гінекологічних захворювань жінок фертильного віку є фріброміома матки. За даними різноманітних джерел, цей доброякісний процес у 20-45 \% випадків асоціюється з непліддям та патологічним перебігом вагітності, а у 50-70 \% випадках $€$ основним показанням до оперативного лікування [1].

Згідно зі статистичними даними, від 25 до $57 \%$ пацієнток гінекологічного відділення становлять хворі 
різної вікової категорії з супутніми екстрагенітальними захворюваннями. У деяких дослідженнях зазначено, що в структурі супутньої екстрагенітальної патології 50 60 \% складають дисфрункціональні розлади та органічні ураження щитоподібної залози [2-4]. У дослідженні [5] було доведено, що захворювання щитоподібної залози та міома матки поєднуються за принципом спорідненості етіологічних фракторів або патогенезу. Це, у свою чергу, призводить до фрормування поліморбідності та важких клінічних проявів основного захворювання.

Перебіг поєднаного патологічного процесу супроводжується психоемоційними порушеннями, погіршенням фрізичного здоров'я та зумовлює виникнення тимчасової непрацездатності на тривалий термін [6, 7]. Таким чином, значна увага приділяється дослідженню психічного стану та показників якості життя даної категорії пацієнтів [8-10].

Деякі автори вважають, що міому матки можна розглядати як психосоматичне захворювання: у таких пацієнток частіше зустрічаються тривожні розлади особистості, неврастенії і депресії [11].

Визначення якості життя полягає у вивченні різносторонньої інформації про фрізичний, психоемоційний та соціальний статус життєдіяльності людини. Тому на сьогодні в наукових дослідженнях часто використовують поєднання поняття - здоров'я та його вплив на якість життя (Health related quality of life (HRQL)). Якість життя відображає всі складові, які пов'язані та не пов'язані зі здоров'ям, і допомагає диференційовано вивчати вплив захворювання та лікування на функкіональний стан пацієнта.

Отже, оцінка психоемоційного статусу та показників якості життя пацієнток із фріброміомою матки має важливе прогностичне значення та визначає можливість їх використання як під час вибору оптимальної тактики лікування захворювання, так і при підготовці індивідуальної програми реабілітації жінок у післяопераційному періоді.

META ДОСЛІДЖЕННЯ - оцінити пСихоемоційний статус і показники якості життя в жінок із фріброміомою матки та поєднаною дисфункцією щитоподібної залози.

МАТЕРІАЛИ ТА МЕТОДИ. Для реалізації поставленої мети нами проведено обстеження 35 жінок (основна група) 3 фріброміомою матки та поєднаною дисфункцією щитоподібної залози у віці від 35 до 45 років. До контрольної групи ввійшли 20 практично здорових невагітних жінок відповідного віку.

Оцінку психоемоційного статусу проводили згідно 3 даними анкети-опитувальника з використанням методики, розробленої Ч. Д. Спілбергером і адаптованої Ю. Л. Ханіним, для визначення особистісної та реактивної тривожності та тесту Бека з метою встановлення рівня депресії.

Оцінювання показників якості життя проведено шляхом анкетування за допомогою спеціально розробленого опитувальника «Симптоми фріброміоми матки та якість життя» (Uterine Fibroid Symptom and Quality of Life (UFS-QOL)). В результаті обстеження отримано дані, які характеризують загальну, соціальну, медичну, емоційну та сексуальну сорери життя кожної пацієнтки.

РЕЗУЛЬТАТИ ДОСЛІДЖЕННЯ ТА ЇХ ОБГОВОРЕННЯ. Різноманітні позитивні та негативні психоемоційні навантаження виникають навіть у здорових жінок, проте вони не мають клінічної основи. Але надзвичайно сильним емоційним фрактором є виявлення доброякісної пухлини репродуктивної ссрери. Такий стан супроводжується тривогою і страхом за своє здоров'я та, в деяких випадках, може призводити до захворювань внутрішніх органів [11].

Провівши аналіз психоемоційного стану обстежених жінок обох груп з використанням тесту Спілбергера, виявлено більш виражені зміни настрою в осіб основної групи. За результатами цієї методики, сумарна оцінка балів відповідей характеризує ступінь вираженості тривожності - до 30 балів вважається низьким рівнем, від 30 до 45 балів - свідчить про помірний рівень тривожності, 46 балів і більше - високий рівень тривожності.

Наглядні параметри визначеного рівня тривожності відображені на рисунку 1.

Як видно з наведених даних, у жінок із фріброміомою матки було встановлено високий рівень тривожності у 29,8 \% випадків, помірний рівень тривожності - у 42,5\% випадків та низький рівень тривожності - у 27,7 \% обстежень.

Таким чином, у 72,3 \% спостережень констатовано високий та помірний рівні тривожності, що може сприяти появі більш виражених змін, таких, як неврози та астенічні синдроми. В подальшому - бути підґрунтям для розвитку психосоматичних захворювань.

Можна відмітити, що в жінок із диссрункцією щитоподібної залози та фріброміомою матки спостерігалася психотривожна симптоматика, а наявність пухлинного утворення та прогресування ознак захворювання лише поглиблює негативні переживання, приховану тривогу та психоемоційне напруження.

Відомо, що в разі високого рівня тривожності на фоні тривалих негативних емоцій, зміни самопочуття, настрою можуть розвиватись депресивні прояви. Для діагностики таких станів ми використовували методику тестування Бека. За даною методикою, рівень менше 11 балів свідчить про відсутність депресивних проявів; 11-19 балів вказують на початкові симптоми; легкий ступінь депресії знаходиться в межах 20-25 балів та 26-30 балів - стан помірно вираженої депресії.

Результати аналізу отриманих даних наведено на рисунку 2.

Так, початкові симптоми депресії відзначено у 44,9\% пацієнток, легко виражений ступінь - у 19,5 \% та у 35,6 \% обстежених - помірний ступінь тривожності. В результаті аналізу отриманих даних встановлено, що депресивні симптоми спостерігались у пацієнток з фріброміомою, а в контрольній групі таких проявів не відмічено.

Останніми роками порушення сну (інсомнії) різної етіології вважають однією з основних медичних і соці-

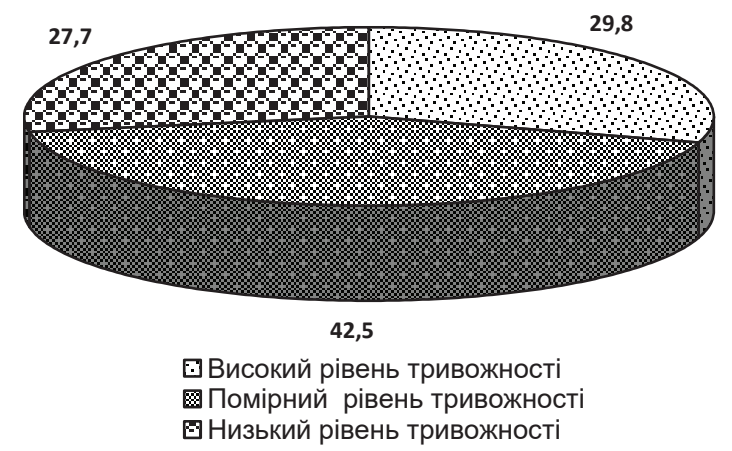

Рис. 1. Вираженість тривожності в жінок основної групи, \%. 


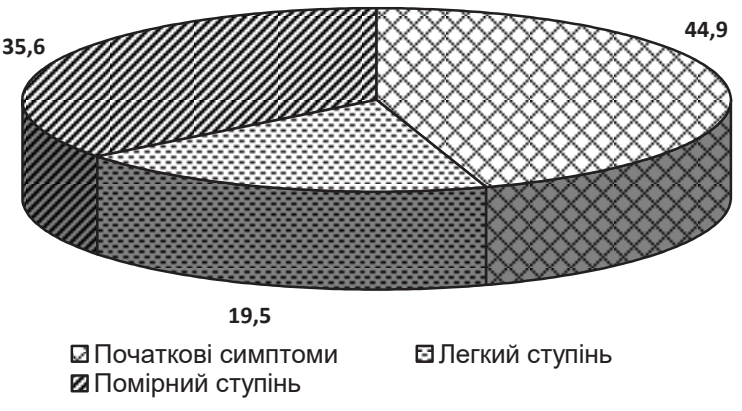

Рис. 2. Депресивні прояви в жінок основної групи, \%.

альних проблем, що є складовою поняття якості життя і спрямовує увагу до різних фрорм патології невротичного, психосоматичного та органічного походження [5].

У нашому дослідженні серед опитаних жінок основної групи 39,4 \% пред'являли скарги на порушення сну, такі, як труднощі засинання, часті та ранні пробудження, відчуття втоми після сну. Тому тривожні розлади та депресивний стан ми відзначили лише в даної категорії пацієнтів.

Слід зазначити, що в процесі дослідження встановлено, що наявність супутньої патології в жінок із фріброміомою негативним чином позначається на характеристиках різних сорер життєдіяльності. Так, серед обстежених пацієнток якість свого життя як низьку оцінили у 42,6 \% випадків в основній групі та 3,5 \% жінок з контрольної групи. Тоді як 55,5 \% осіб контрольної групи характери- зують якість свого життя як високу, в основній групі подібну характеристику навели лише $5 \%$ опитаних. Щодо характеристики інших показників якості життя серед пацієнток основної групи, то результати розподілились таким чином: найбільше негативних тверджень виявилось у сорері здоров'я та емоцій, відповідно, 43,7 \% та 23,5 \% жінок, невдоволеність у професійній діяльності - 21,3%, статевій ссрері - 14,7 \% опитаних.

Таким чином, у процесі використання опитувальника оцінки якості життя було з'ясовано, що ця ланка у пацієнтів з міомою матки суттєво страждає. Особливо це стосується таких параметрів, як здоров'я та емоції. Зазначимо, що такі жінки схильні до частої зміни настрою, тривожності, виникнення депресивних станів, що значно погіршує працездатність у цьому соціально активному віці.

ВИСНОВКИ. Таким чином, можна стверджувати, що наявність фріброміоми матки в поєднанні з порушенням орункціонального стану щитоподібної залози негативно впливає як на психоемоційний стан, так і на якість життя жінок у всіх її ссрерах. Отже, метод лікування даної категорії пацієнтів необхідно поєднувати з індивідуальною психотерапевтичною реабілітацією у зв'язку з їх низькою стресостійкістю та вираженою емоційною нестабільністю.

ПЕРСПЕКТИВИ ПОДАЛЬШИХ ДОСЛІДЖЕНЬ. У ХОДі подальших досліджень отримані дані дозволять оцінити зміни психоемоційного статусу та якості життя жінок внаслідок обраного способу лікування міоми матки та бути показником його ефективності у віддаленому періоді.

\section{СПИСОК ЛІТЕРАТУРИ}

1. Памсрамиров Ю. К. Органосберегающий подход в лечении миомы матки / Ю. К. Памфрамиров, В. А, Заболотнов, О. В. Карапетян // Здоровье женщины. - 2013. - № 1. C. 162-164.

2. Дубчак А. Є. Гіперпластичні процеси ендометрія та функціональний стан щитоподібної залози у жінок із неплідністю / А. Є. Дубчак, О.В.Мілєвський // Одеський медичний журнал. - 2003. - № 4 (78). - С. 31-33.

3. Клініко-діагностичні аспекти порушень репродуктивного здоров'я жінок, які мешкають в йододефіцитних регіонах / Т. Ю. Юзвенко, Б. В. Хабрат, О.О.Литвак [та ін.] // Клінічна ендокринологія та ендокринна хірургія. - 2013. - № 1 (42). - C. $59-61$.

4. Дорогая О. П. Оптимізація методу відновлення репродуктивної фрункції у жінок із субмукозною міомою матки / О. П. Дорогая // Клінічна ендокринологія та ендокринна хірургія. - 2014. - № 3 (48). - С. 47-52.

5. Яворський П. В. Значення коефріцієнта поєднання для кількісної характеристики впливу етіологічних чинників лейоміоми матки / П. В. Яворський // Україна. Здоров'я нації. - 2012. - № 3 (23). - С. 294-299.
6. Sabry M. Innovative oral treatments of uterine leiomyoma / M. Sabry // Obstetrics Gynecology International. - 2012. Vol. 2. - P. 1-10.

7. Кичигин О. В. Факторы риска развития миомы матки и качество жизни пациенток, оперированных по поводу миомы матки / О. В. Кичигин, И. М. Арестова, Ю. В. Занько // Охрана материнства и детства. - 2013. - № 2 (22). - С. 36-41.

8. Макарчук О. М. Порівняльне оцінювання показників якості життя у пацієнток після оперативного лікування з приводу міоми матки / О. М. Макарчук, Г. М. Гаврилюк // Здоровье женщины. - 2016. - № 8 (114). - С. 94-97.

9. Якість життя у жінок з лейоміомою матки після емболізації маткових артерій / О.В.Литвиненко, А. М. Громова, Р. П. Сакевич, Б. Фадда // Світ медицини та біології. - 2013. - № 2. - С. 140-143.

10. Нужнов С. Г. Оценка качества жизни жещин с миомой матки при эмболизации маточных артерий и гормональном лечении / С. Г. Нужнов, Е. В. Брюхина, Е. Н. Усольцева // Вестник ЮУрГУ. - 2010. - № 6. - С. 44-47.

11. Health-related quality of life after laparoscopically assisted vaginal hysterectomy: is uterine weight a major factor? / P. L. Torng, W. C. Chang, J. S. Hwang [et al.] // Qual. Life Res. - 2007. - Vol. 16, No. 2. - P. 227-237. 


\section{REFERENCES}

1. Pamfamirov, Yu.K., Zabolotnov, V.A., \& Karapetyan, O.V. (2013). Organosberegayushchiy podkhod $v$ lechenii miomy matki [Organosaving approach in the treatment of uterine myoma]. Zdorovye zhenshchiny - Woman's Health, 1, 162-164 [in Russian].

2. Dubchak, A.Ye., \& Milievskyi, O.V. (2003). Hiperplastychn protsesy endometriia ta funktsionalnyi stan shchytopodibnoi zalozy u zhinok iz neplidnistiu [Hyperplastic processes of endometrium and functional state of the thyroid gland in women with infertility]. Odeskyi medychnyi zhurnal - Odesa Medical Journal, 4 (78), 31-33 [in Ukrainian].

3. Yuzvenko, T.Yu., Khabrat, B.V., Lytvak, O.O., Lysenko, B.M., \& Hyriavenko, O.Ya. (2013). Kliniko-diahnostychni aspekty porushen reproduktyvnoho zdorovia zhinok, yaki meshkaiut $v$ yododefitsytnykh rehionakh [Clinical and diagnostic aspects of reproductive health disorders of women living in iodine deficient regions]. Klinichna endokrynolohiia ta endokrynna khirurhiia Clinical Endocrinology and Endocrine Surgery, 1 (42), 59-61 [in Ukrainian].

4. Dorohaia, O.P. (2014). Optymizatsiia metodu vidnovlennia reproduktyvnoi funktsii u zhinok iz submukoznoiu miomoiu matky [Optimization of the method of restoration of the reproductive function in women with submucous uterine myoma]. Klinichna endokrynolohiia ta endokrynna khirurhiia - Clinical Endocrinology and Endocrine Surgery, 3 (48), 47-52 [in Ukrainian].

5. Yavorskyi, P.V. (2012). Znachennia koefitsiienta poiednannia dlia kilkisnoi kharakterystyky vplyvu etiolohichnykh chynnykiv leiomiomy matky [The value of the combination factor for quantitative characteristics of the influence of the etiological factors of uterine leiomyoma]. Ukraina. Zdorovia natsii - Ukraine. Health of the Nation, 3 (23), 294-299 [in Ukrainian].
6. Sabry, M. (2012). Innovative oral treatments of uterine leiomyoma. Obstetrics Gynecology International, 2, 1-10.

7. Kichigin, O.V., Arestova, I.M., \& Zanko, Yu.V. (2013). Faktory riska razvitiya miomy matki i kachestvo zhyzni patsyentok, operyrovannykh po povodu miomy matki [Risk factors for the development of uterine fibroids and the quality of life of patients operated for uterine myoma]. Okhrana materinstva i detstva - Protection of Motherhood and Childhood, 2 (22), 36-41 [in Russian].

8. Makarchuk, O.M., \& Havryliuk, H.M. (2016). Porivnialne otsiniuvannia pokaznykiv yakosti zhyttia u patsiientok pislia operatyvnoho likuvannia z pryvodu miomy matky [Comparative assessment of quality of life in patients after surgical treatment for uterine fibroids]. Zdorovye zhenshchiny - Woman's Health, 8 (114), 94-97 [in Ukrainian].

9. Lytvynenko, O.V., Hromova, A.M., Sakevych, R.P., \& Fadda, B. (2013). Yakist zhyttia u zhinok z leiomiomoiu matky pislia embolizatsii matkovykh arterii [Quality of life in women with uterine leiomyoma after uterine artery embolization]. Svit medytsyny ta biolohii - World of Medicine and Biology, 1, 162164 [in Ukrainian].

10. Nuzhnov, S.G., Bryukhina, E.V., \& Usoltseva, E.N. (2010). Otsenka kachestva zhyzni zhenshchin s miomoy matki pri embolizatsyi matochnykh arteriy i gormonalnom lechenii [Assessment of the quality of life of women with uterine myoma in embolization of uterine arteries and hormonal treatment]. Vestnik YuUrHU - Bulletin of the SUrSU, 2, 44-47 [in Russian].

11. Torng, P.L., Chang, W.C., Hwang, J.S., Hsu, W.C., Wang, J.D., Huang, S.C., \& Chen C.F. (2007). Health-related quality of life after laparoscopically assisted vaginal hysterectomy: is uterine weight a major factor? Qual. Life Res., 2 (16), 227-237. 